\title{
Plant community responses to short duration grazing in tallgrass prairie
}

\author{
ROBERT L. GILLEN, F. TED MCCOLLUM, MARK E. HODGES, JOE E. BRUMMER, AND KENNETH W. TATE
}

\section{Abstract}

A key to management of short duration grazing systems is maintaining proper rest periods for individual pastures, but information on the necessary length of rest periods for tallgrass prairie is limited. Research hypotheses for this study were that tallgrass prairie plant communities would respond differently to grazing schedules incorporating rest periods of varying lengths and that this response would be dependent on stocking rate. Treatments consisted of 3 grazing schedules $(2,3$, or 4 rotation cycles per 152 day grazing season) and 2 stocking rates (1.6 and 2.2 times the moderate continuous rate). Plant frequency, standing crop, species composition, and forage utilization were sampled from 1985 to 1989. Precipitation was above average in 4 of the 5 study years. Grazing schedule did not affect any vegetation parameter over time. Stocking rate did not affect plant frequency or species composition. Standing crop was reduced and forage utilization increased at the higher stocking rate but these effects were consistent over time. Frequency of western ragweed [A mbrosia psilostachya DC.] and the relative species composition of the forb component increased in all grazed pastures compared to ungrazed pastures. The overall lack of major treatment effects was attributed to favorable precipitation, spring burning, and the initial high-seral successional stage of the experimental pastures.

\section{Key Words: rotation graxing, stocking rate, grazing systems}

Short duration grazing (SDG) is a multi-pasture, one-herd grazing system that involves rapid rotation of livestock. A key to management of short duration grazing systems is maintaining proper rest periods for individual pastures. Rest periods should be long enough to allow the most severely grazed plants to recover from grazing before animals re-enter the pasture (Savory 1988). General recommendations have been to allow 30-90 day rest periods with shorter rest periods during rapid plant growth and longer rest periods as plant growth slows.

Most research studies have compared SDG at 1 grazing schedule to continuous grazing. Vegetation response to SDG in such studies has been mixed. Hart et al. (1988), Heitschmidt et al. (1987), and Pitts and Bryant (1987) reported little impact on herbage standing crop or species composition. Thurow et al. (1988) found that SDG at a stocking rate $76 \%$ greater than moderate continuous grazing resulted in a shift from midgrass to shortgrass dominance. Only 2 studies have specifically studied different combinations of rest and graze periods within SDG (Denny and Barnes 1977, Tainton et al. 1977). Neither of these studies reported a vegetation response to different grazing schedules.

No research information currently exists for tallgrass prairie ecosystems to determine how long plants need to recover from grazing or how long this time period might vary with season. Practical success has been reported with average grazing cycles of 7

\footnotetext{
Authors are associate professor, Agronomy Department, associate professor, Animal Science Department, former senior ayriculturist, former graduate research assistant, and senior agriculturist, Agronomy Department, Oklahoma State University, Stillwater 74078. The authors thank DeAnn Lowder, Dwayne Rice, Russ Wright, John Altom. and Terry Carroll for assistance in data collection.

Published with approval of the Director, Oklahoma Agricultural Experiment Station, as JA-5729.

Manuscript accepted 18 June 1990.
}

days grazing with 42 days rest (Merrill 1983).

The primary research hypothesis for this study was that tallgrass plant communities would show different plant successional responses when intermittently grazed under schedules with rest periods of varying lengths. An additional hypothesis was that the response to grazing schedule would be dependent on stocking rate.

\section{Study Area}

The study area was located on the Oklahoma State University Agronomy Research Range approximately $21 \mathrm{~km}$ southwest of Stillwater, Oklahoma $\left(36^{\circ} 3^{\prime} \mathrm{N}, 97^{\circ} 14^{\prime} \mathrm{W}\right)$. The climate is continental with an average frost-free growing period of 204 days extending from April to October. Average precipitation at Stillwater is $831 \mathrm{~mm}$ with $65 \%$ falling as rain from May to October. Mean temperature is $15^{\circ} \mathrm{C}$ with average minimum and maximum temperatures ranging from $-4.3^{\circ} \mathrm{C}$ in January to $34^{\circ} \mathrm{C}$ in August (Myers 1982).

Soils found on the area are primarily the Grainola and Coyle series, comprising approximately 60 and $35 \%$ of the area, respectively. The Grainola series has a loam surface with silty clay loam subsoil and is a member of the fine, mixed, thermic family of Vertic Haplustalfs. The Coyle series has a fine sandy loam surface with sandy clay loam subsoil and is a member of the fine-loamy, siliceous, thermic family of Udic Argiustolls. Range site classification of the Grainola soil is shallow prairie and the Coyle soil is loamy prairie.

The study area was established in 1984 on native tallgrass prairie. The area was dominated by big bluestem [Andropogon gerardii Vitman], little bluestem [Schizachyrium scoparium (MichX.) Nash], and switchgrass [Panicum virgatum L.], each comprising approximately $20 \%$ of the standing crop by weight in August 1984. Other important species included indiangrass [Sorghastrum nutans (L.) Nash], tall dropseed [Sporobolus asper (Michx.) Kunth], and western ragweed [Ambrosia psilostachya DC.].

\section{Methods}

Experimental treatments consisted of 3 grazing schedules under 2 stocking rates. Grazing schedule treatments were based on the number of complete grazing cycles $(2,3$, or 4$)$ in an 8-pasture rotation that could be completed during a 152-day spring-summer grazing season. Within grazing schedule treatments, shorter graze/ rest periods were used at the beginning of the grazing season when the vegetation was in a rapid growth stage. Graze/rest periods were gradually lengthened during the season as the vegetation matured (Table 1). Each treatment pasture received 19 total days of grazing. Grazing began between 1 April and 1 May depending on the onset of rapid forage growth from year to year. All pastures were burned approximately 4 weeks before the starting dates from 1985 to 1988. The pastures were also burned in late March in 1984, the year before treatments were first applied. Forage levels were low in the spring of 1989 because of drought in the previous summer and the pastures were not burned.

Initial stocking rate treatments were targeted for 1.3 (light) and 1.8 (heavy) times the Soil Conservation Service recommended rate 
Table 1. Days of grazing and rest per cycle for the 3 grazing schedule treatments.

\begin{tabular}{|c|c|c|c|c|c|c|c|c|c|c|}
\hline \multirow{2}{*}{ Grazing schedule } & \multicolumn{2}{|c|}{ Cycle 1} & \multicolumn{2}{|c|}{ Cycle 2} & \multicolumn{2}{|c|}{ Cycle 3} & \multicolumn{2}{|c|}{ Cycle 4} & \multicolumn{2}{|c|}{ Mean } \\
\hline & DG' $^{\prime}$ & $\mathrm{DR}^{2}$ & DG & DR & DG & DR & DG & DR & DG & DR \\
\hline & $\begin{array}{l}6 \\
4 \\
3\end{array}$ & $\begin{array}{l}42 \\
28 \\
21\end{array}$ & $\begin{array}{r}13 \\
6 \\
4\end{array}$ & $\begin{array}{l}91 \\
42 \\
28\end{array}$ & $\begin{array}{l}\overline{9} \\
5\end{array}$ & $\begin{array}{l}\overline{63} \\
35\end{array}$ & $\overline{-}$ & $\overline{-}$ & $\begin{array}{r}10 \\
6 \\
5\end{array}$ & $\begin{array}{l}67 \\
44 \\
33\end{array}$ \\
\hline
\end{tabular}

IDG = Days of grazing per cycle.

${ }^{2} \mathrm{DR}=$ Days of rest per cycle.

for the range sites under study. Three animals were grazed on 0.40 -ha pastures to obtain the light stocking rate while 5 animals were grazed on 0.48-ha pastures to obtain the heavy stocking rate. Stocker steers and heifers with average summer weights of approximately $315 \mathrm{~kg}$ were used in 1985 and 1986. Forage utilization levels were light during these years (Brummer et al. 1988) so dry cows with average weights of $510 \mathrm{~kg}$ were used in place of the yearlings in 1987 and 1989. A mixture of cows and yearlings were used in 1988. Poor growing conditions in the summer of 1988 required us to shorten the grazing season which resulted in a reduced stocking rate. Stocking rates for the light and heavy treatments were 99 and 137 animal-unit-days per ha (AUD ha ${ }^{-1}$ ) for 1985-86, 159 and 221 AUD ha ${ }^{-1}$ for 1987 and 1989 , and 86 and 116 AUD ha $^{-1}$ for 1988. Average stocking rates for the entire study were 120 and 166 AUD $\mathrm{ha}^{-1}$ for the light and heavy treatments. Moderate stocking for continuous summer grazing on these range sites is 65-85 AUD $\mathrm{ha}^{-1}$.

Treatments were applied using a simulated 8-pasture short duration grazing system. Pasture number 4 in the rotation was used to determine the mean system effect. Grazing schedules and stocking rates were arranged factorially in a randomized complete block design with 3 replications. In addition, 1 ungrazed pasture was included within each block as a check of plant community responses without the influence of grazing.

Frequency of rooted plants of the major species on the study area was sampled in $100,0.1-\mathrm{m}^{2}$ plots in all treatment pastures in late July of each year. Species composition was determined in late September each year with the dry-weight-rank method (Gillen and Smith 1986) by sampling $50,0.1-\mathrm{m}^{2}$ plots in all pastures. Species composition components were big bluestem, little bluestem, switchgrass, indiangrass, other grasses, and forbs. Indiangrass and other grasses were grouped together in 1985 but were separated in the remaining years. Total standing crop was measured by clipping all standing herbage to ground level in 15 of the plots used for composition estimates. Forage utilization was calculated within each block by first subtracting standing crop in grazed pastures from standing crop in the ungrazed pasture and then dividing by standing crop in the ungrazed pasture.

All data were analyzed using analysis of variance techniques for a randomized complete block design with repeated measures (Milliken and Johnson 1984). Grazing schedule and stocking rate were whole plot factors with year as the repeated factor. Pastures were experimental units. The arcsin transformation was applied before the analysis of variance to all dependent variables that were percentages. Grazing treatment (grazing schedule and stocking rate) by year interactions were the main focus of the analysis. If year interactions were not significant $(P=0.05)$, the plant community did not respond to the grazing treatments over time. When significant treatment differences were indicated by the F-tests, treatment means were compared using least significant differences (LSD). In cases where grazing schedule or stocking rate effects were not significant, responses were averaged over all grazing treatments and comparisons were made between grazed and ungrazed treatments.

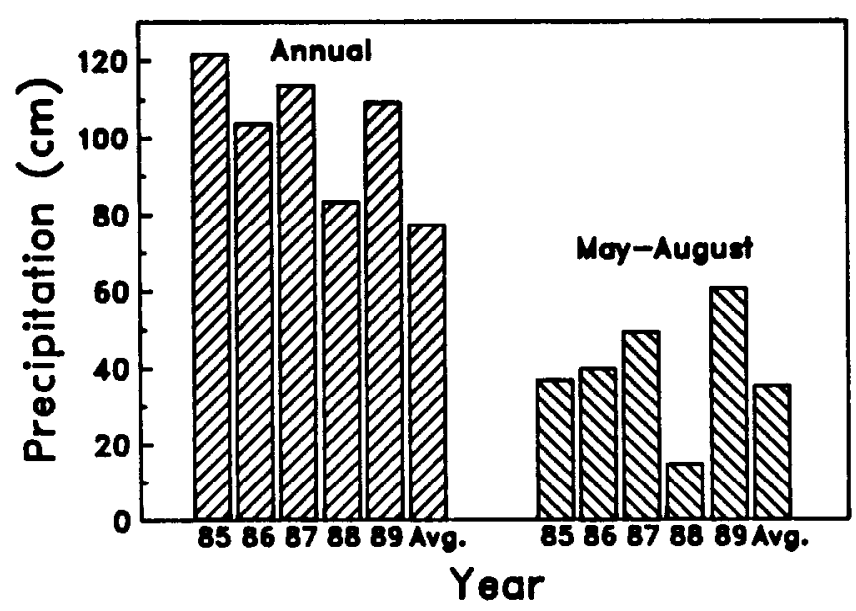

Fig. 1. Precipitation received at the study site from 1985 to 1989. Annual precipitation was totaled on a November to October basis.

\section{Results and Discussion}

\section{Precipitation}

Precipitation for the entire study period was favorable for plant growth (Fig. 1). Annual precipitation (November to October) was above the long-term average in all years. Precipitation during the main portion of the growing season was also above average except for 1988 . Only $2.5-3.0 \mathrm{~cm}$ of rain was received per month from May to August 1988. Ungrazed standing crop in September was $2,200 \mathrm{~kg} \mathrm{ha}^{-1}$ in 1988 compared to an average of $6,930 \mathrm{~kg} \mathrm{ha}^{-1}$ in the other study years. In contrast, May-August rainfall for 1989 was one of the highest amounts on record and was evenly distributed throughout the period.

\section{Standing Crop and Utilization}

Standing crop in September was not affected by grazing schedule (Table 2) even though the timing of the grazing periods was quite different. An earlier study conducted at this site (Brummer et al. 1988) showed no short-term effects on growth rates in response

Table 2. Herbage standing crop (kg ha-1) and species composition (\%) in September as affected by grazing schedule and stocking rate averaged over years.

\begin{tabular}{|c|c|c|c|c|c|}
\hline \multirow{2}{*}{$\begin{array}{l}\text { Herbage } \\
\text { component }\end{array}$} & \multicolumn{3}{|c|}{ Grazing schedule } & \multicolumn{2}{|c|}{ Stocking rate } \\
\hline & 2-cycle & 3-cycle. & 4-cycle & Light & Heavy \\
\hline Standing crop & 3270 & 3330 & 3100 & $3490^{\mathrm{al}}$ & $2970^{b}$ \\
\hline Big bluestem & 16 & 16 & 14 & 16 & 15 \\
\hline Little bluestem & 20 & 22 & 21 & 23 & 18 \\
\hline Switchgrass & 13 & 14 & 13 & 15 & 12 \\
\hline Indiangrass & 18 & 15 & 12 & 14 & 16 \\
\hline Other grasses & 29 & 29 & 33 & 27 & 34 \\
\hline Forbs & $6^{2}$ & $5^{a}$ & $8^{b}$ & $6^{x}$ & $7^{y}$ \\
\hline
\end{tabular}

'Means within rows and treatment factors with different superscripts are significantly different, $\mathbf{P}=0.05$. Absence of superscripts indicates no significant differences.

to grazing schedules and this response did not change over a longer time period. Tainton et al. (1977) studied rest periods of 20,40 , or 60 days coupled with grazing periods of 2,10 , or 20 days. These treatments had no significant effect on peak standing crop although longer rests and shorter graze periods tended to increase standing crop.

As would be expected from the standing crop results, utilization was also unaffected by grazing schedule. Utilization averaged over years was 45,44 , and $47 \%$ for the 2,3 , and 4-cycle grazing schedules, respectively.

The heavy stocking rate significantly reduced September stand- 

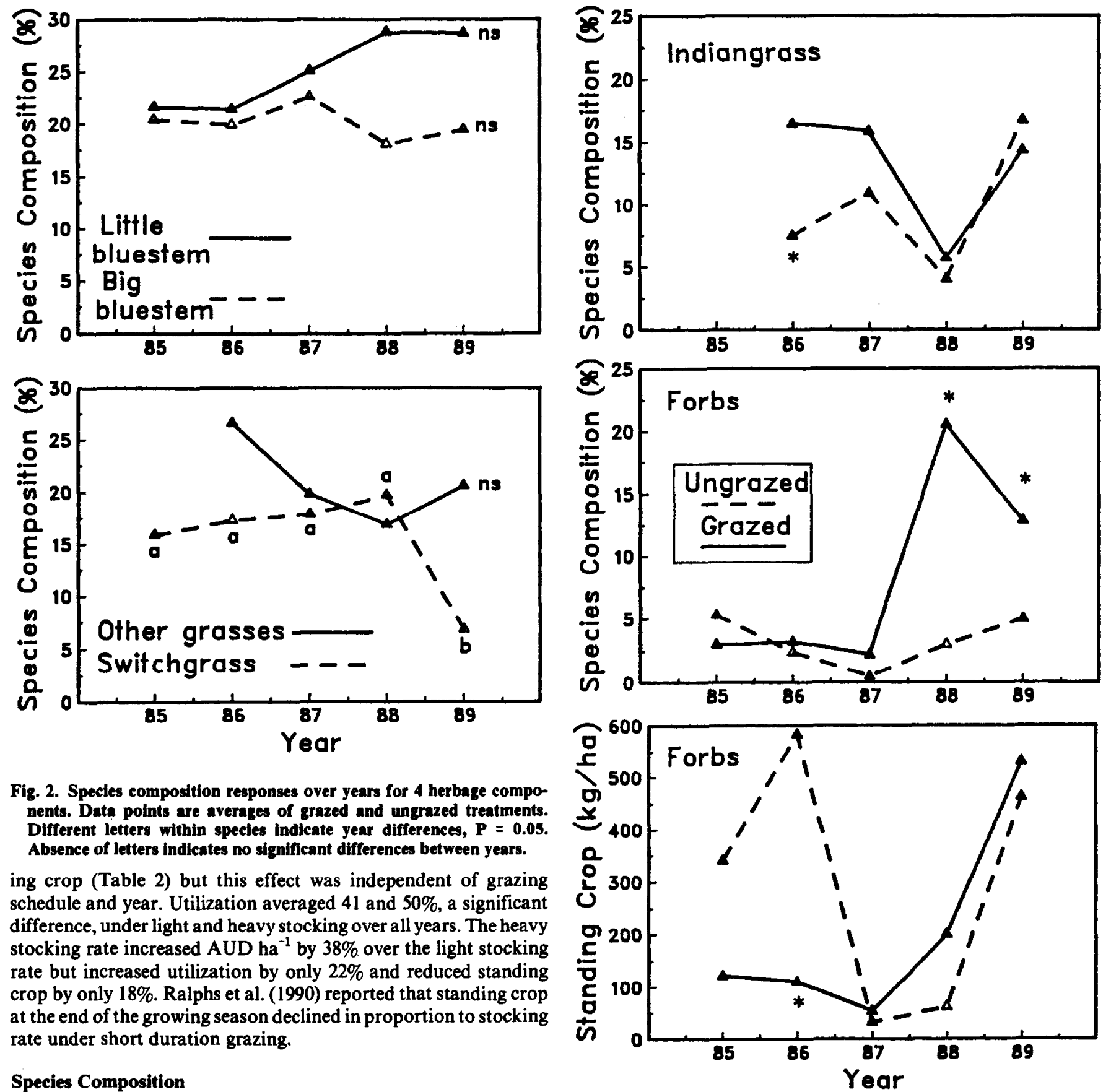

Fig. 2. Species composition responses over years for 4 herbage components. Data points are averazes of grazed and ungrazed treatments. Different letters within species indicate year differences, $P=0.05$. Absence of letters indicates no significant differences between years.

ing crop (Table 2) but this effect was independent of grazing schedule and year. Utilization averaged 41 and $50 \%$, a significant difference, under light and heavy stocking over all years. The heavy stocking rate increased AUD ha ${ }^{-1}$ by $38 \%$ over the light stocking rate but increased utilization by only $22 \%$ and reduced standing crop by only $18 \%$. Ralphs et al. (1990) reported that standing crop at the end of the growing season declined in proportion to stocking rate under short duration grazing.

\section{Species Composition}

Species composition did not differ among grazing schedules. Forb composition was higher under 4-Cycle grazing (Table 2) but this difference was constant over the 5-year sampling period and, therefore, may have been present before the study began. Denny and Barnes (1977) found no effect on basal cover of vegetation from rest periods ranging from 15 to 140 days. Their experiment covered a 5 -year period with 3 dry years followed by 2 wet years.

Composition of grass species was not affected by stocking rate. Forb composition was slightly higher under heavy stocking (Table 2). These differences are probably not biologically significant. Hart et al. (1988) found no response of species composition to stocking rate under short duration or continuous grazing. Ralphs et al. (1990) reported a decline in desirable midgrasses and an increase in poisonous forbs under short duration. The vegetation changes occurred at all stocking rates ranging from $100 \%$ to $250 \%$ of moderate continuous stocking. Thurow et al. (1988) also observed a decline in midgrasses and an increase in shortgrasses under short

Fig. 3. Relative composition of indiangrass and forbs and standing crop of forbs as affected by the interaction of presence of grazing and year. Asterisks indicate differences between grazing treatments within years, $P$ $=0.05$.

duration grazing at heavy stocking rates. Butler and Briske (1988) felt that little bluestem would decline under short duration grazing at increased stocking rates because large plants would break up into smaller individuals less able to withstand environmental stresses and interspecific competition.

Big bluestem, little bluestem, switchgrass, and other grasses did not differ between grazed treatments and ungrazed pastures. Of these components, only switchgrass was significantly affected by years (Fig. 2). Switchgrass was apparently seriously reduced by the summer drought of 1988.

Indiangrass was initially lower in the ungrazed pastures but quickly reached a level equal to the grazed pastures (Fig. 3). This 
result was due mainly to an increase in the ungrazed pastures rather than a decrease in the grazed pastures. Indiangrass declined dramatically during the drought year but recovered immediately.

Relative forb composition in the grazed pastures increased over six-fold during the drought year but then declined the next year (Fig. 3). Forb composition in the ungrazed pastures increased only moderately in response to wet and dry years. However, actual standing crop of forbs only differed between grazed and ungrazed pastures in 1 year and in that case more forbs were present in the ungrazed pastures (Fig. 3). Much of the increase in forb composition in grazed pastures in 1988 was a reflection of selective use of grasses and heavier than normal utilization on grasses in the dry year. On the other hand, the large increase in forb standing crop in 1989 was due to abundant moisture and was partially offset by increased production of grasses so that percent composition of forbs actually declined in the grazed pastures.

\section{Plant Frequency}

Grazing schedule or stocking rate did not account for changes in plant frequency over time for any of the species monitored. Several species exhibited year to year fluctuations in frequency but the changes were similar over all grazing treatments.
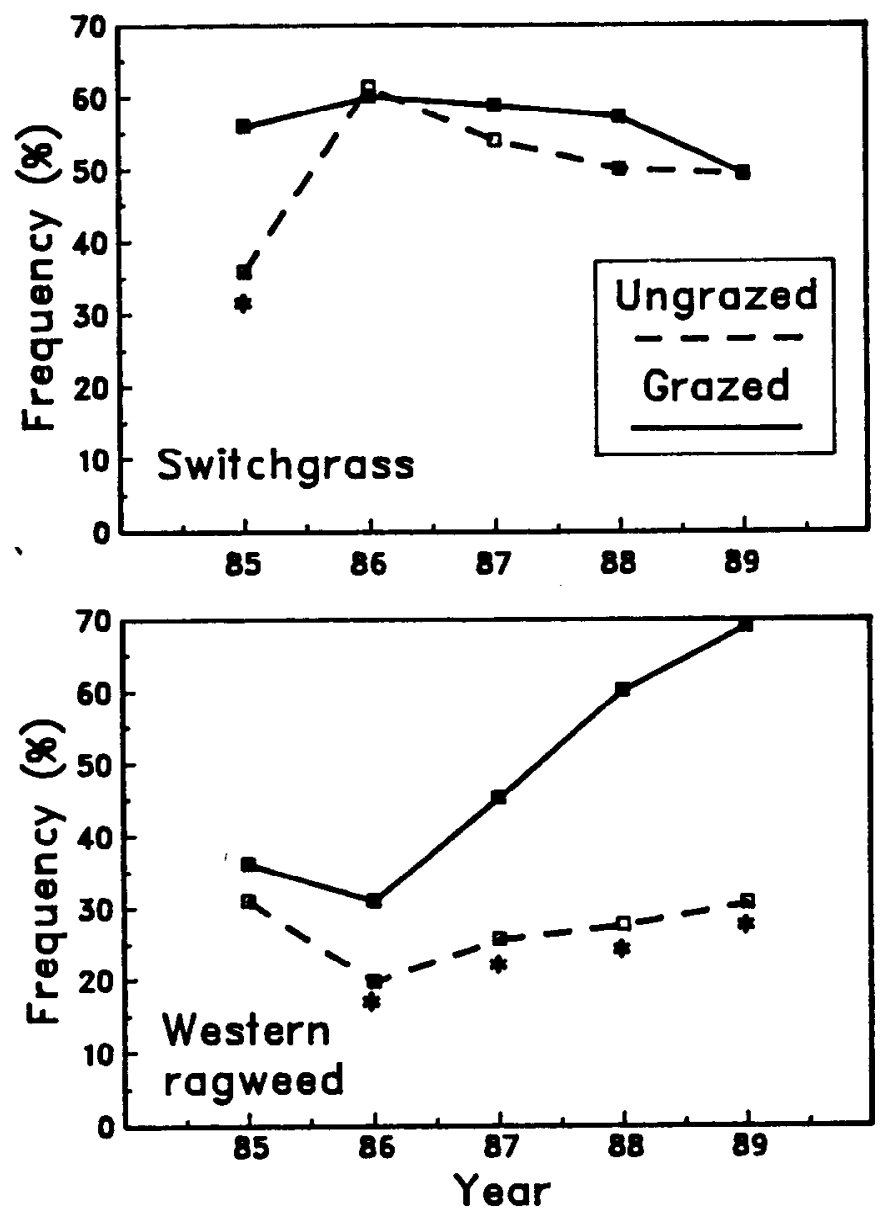

Fig. 4. Plant frequency as affected by the interaction of presence of graxing and year for 2 species. Asterisks indicate differences between grazing treatments within years, $P=0.05$.

Switchgrass reacted differently in the grazed and ungrazed pastures over years (Fig. 4). Switchgrass was less frequent in the ungrazed pastures in the first year and then increased, but the species remained constant in the grazed pastures. The frequency measurements do not show the same sharp decline in switchgrass in 1989 that was seen in the composition data.
Western ragweed frequency continually increased in the grazed pastures compared to the ungrazed pastures (Fig. 4). This increase occurred even in years such as 1986 and 1987 when forb composition in the grazed pastures was at its lowest point (Fig. 3). Western ragweed contributed $70-80 \%$ of the forb component. Such an increase in ragweed frequency would be considered an indication of undesirable species change.

Frequency of all other species monitored was not different between grazed and ungrazed pastures. The response of these species over time (Table 3 ) should be a gauge of general environmental conditions including the impact of spring burning. An

Table 3. Plant frequency by years averaged over grazed and ungrazed treatments.

\begin{tabular}{lccccc}
\hline \hline & \multicolumn{5}{c}{ Year } \\
\cline { 2 - 6 } Species & 85 & 86 & 87 & 88 & 89 \\
\hline Little bluestem & $64^{\mathrm{bcl}}$ & $47^{\mathrm{a}}$ & $54^{\mathrm{ab}}$ & $73^{\mathrm{c}}$ & $67^{\mathrm{bc}}$ \\
Big bluestem & 56 & 61 & 53 & 56 & 58 \\
Indiangrass & $29^{\mathrm{a}}$ & $26^{\mathrm{a}}$ & $36^{\mathrm{ab}}$ & $44^{\mathrm{b}}$ & $41^{\mathrm{b}}$ \\
Tall dropseed & $42^{\mathrm{c}}$ & $30^{\mathrm{b}}$ & $19^{\mathrm{a}}$ & $37^{\mathrm{bc}}$ & $32^{\mathrm{b}}$ \\
Sidecats grama & $11^{\mathrm{ab}}$ & $7^{\mathrm{a}}$ & $18^{\mathrm{bc}}$ & $16^{\mathrm{bc}}$ & $22^{\mathrm{c}}$ \\
Scribner's dicanthelium & $53^{\mathrm{b}}$ & $27^{\mathrm{a}}$ & $58^{\mathrm{b}}$ & $61^{\mathrm{b}}$ & $66^{\mathrm{b}}$ \\
Arrowfeather threeawn & $18^{\mathrm{c}}$ & $8^{\mathrm{b}}$ & $2^{\mathrm{a}}$ & $4^{\mathrm{a}}$ & $3^{\mathrm{a}}$ \\
Japanese brome & $20^{\mathrm{b}}$ & $3^{\mathrm{a}}$ & $<1^{\mathrm{a}}$ & $<1^{\mathrm{a}}$ & $<1^{\mathrm{a}}$ \\
Daisy fleabane & $2^{\mathrm{a}}$ & $9^{\mathrm{b}}$ & $1^{\mathrm{a}}$ & $3^{\mathrm{a}}$ & $2^{\mathrm{a}}$ \\
Western yarrow & $11^{\mathrm{b}}$ & $2^{\mathrm{a}}$ & $4^{\mathrm{ab}}$ & $5^{\mathrm{ab}}$ & $9^{\mathrm{b}}$ \\
Catclaw sensitivebriar & 7 & 6 & 7 & 8 & 8 \\
Blackeyedsusan & $26^{\mathrm{b}}$ & $2^{\mathrm{a}}$ & $1^{\mathrm{a}}$ & $3^{\mathrm{a}}$ & $50^{\mathrm{c}}$ \\
\hline
\end{tabular}

'Means within species with different superscripts are significantly different, $P=0.05$. Absence of superscripts indicates no significant differences.

overall increase in indiangrass and decreases in tall dropseed and arrowfeather threeawn [Aristida purpurescens Poir.] indicate an increase in range condition (Sims and Dwyer 1965). However, the increase in sideoats grama [Bouteloua curtipendula (Michx.) Torr.] suggests the opposite. Japanese brome [Bromus japonicus Thunb.] was virtually eliminated from the study area after 1986. This cool-season annual grass is particularly susceptible to spring burning (Gillen et al. 1987, Gartner et al. 1978). The biennial blackeyedsusan [Rudbeckia hirta L.], 1985 and 1989, and the annual daisy fleabane [Erigeron strigosus Muhl. ex Willd.], 1986, illustrate the fluctuations opportunistic species often exhibit in response to specific environmental conditions favorable to their establishment. Little bluestem, Scribner's dicanthelium [ Dicanthelium oligonsanthes (J.A. Schultes) Gould], and western yarrow [Achillea millefolium $\mathrm{L}$.] fluctuated over years with no clear direction. Big bluestem and catclaw sensitivebriar [Schrankia uncinata Willd.] did not change over years.

\section{Conclusion}

Grazing schedule and stocking rate had little effect on the tallgrass prairie plant community in this study. A high seral plant community was maintained under all experimental treatments. This leads to the rejection of the research hypotheses. The lack of stocking rate effect is especially surprising since the stocking rates studied were at least $50 \%$ above moderate rates. Three factors probably contributed to these results. First, precipitation was well above average in 4 out of the 5 years of the study. Second, spring burning was applied in the year before treatment initiation and in the first 4 years of treatment application. Spring burning is generally beneficial to tallgrass prairie plant communities and favors higher seral species such as big bluestem that heavy grazing reduces (Towne and Owensby 1984). Third, the plant community was in a high-seral state initially. There was little potential for an upward range trend while the vigor of the dominant species would tend to 
buffer any downward trend.

The only indication of an overall grazing effect was the increase in the frequency of western ragweed in the grazed pastures compared to ungrazed areas. The ungrazed pastures are probably the most rigorous standard of comparison possible since they received several spring burns and no grazing during the growing season. However, no major changes in the grazed plant communities could be detected and the grazed pastures remained in a high-seral successional stage. A return to average or below-average precipitation patterns may eventually trigger different vegetation responses.

\section{Literature Cited}

Brummer, J.E., R.L. Gillen, and F.T. McCollum. 1988. Herbage dynamics of tallgrass prairie under short duration grazing. J. Range Manage. 41:264-266.

Butler, J.L., and D.D. Briske. 1988. Population structure and tiller demography of the bunchgrass Schizachyrium scoparium in response to herbivory. Oikos 51:306-312.

Denny, R.P., and D.L. Barnes. 1977. Trials of multi-paddock grazing systems on veld. 3. A comparison of six grazing procedures at two stocking rates. Rhod. J. Agr. Res. 15:129-142.

Gartner, F.R., R.I. Butterfield, W.W. Thompson, and L.R. Roath. 1978. Prescribed burning of range ecosystems in South Dakota, p. 687-690. In: Proc. Ist Int. Rangeland Congr. (ed. D.N. Hyder), Soc. Range Manage. Denver, Colo.

Gillen, R.L., and E.L. Smith. 1986. Evaluation of the dry-weight-rank method for determining species composition in tallgrass prairie. J. Range Manage. 39:283-285.

Gillen, R.L., D. Rollins, and J.F. Stritzke. 1987. Atrazine, spring burning, and nitrogen for improvement of tallgrass prairie. J. Range Manage. 40:444-447.
Hart, R.H., M.J. Samuel, P.S. Test, and M.S. Smith. 1988. Cattle, vegetation, and economic responses to grazing systems and grazing pressure. J. Range Manage. 41:282-286.

Heitschmidt, R.K., S.L. Dowhower, and J.W. Walker. 1987. 14-vs. 42paddock rotational grazing: aboveground biomass dynamics, forage production, and harvest efficiency. J. Range Manage. 40:216-223.

Merrill, J. 1983. The XXX Ranch: managing range for ecology and economy, p. 86-95. In: 1983 Yearbook of Agriculture. USDA.

Milliken, G.A., and D.E. Johnson. 1984. Analysis of messy data. Lifetime Learning Publications, Belmont, Calif.

Myers, H. 1982. Climatological data of Stillwater, Oklahoma. 1893-1980. Okla. Agr. Exp. Sta. Res. Rep. P-821.

Pitts, J.S., and F.C. Bryant. 1987. Steer and vegetation response to short duration and continuous grazing. J. Range Manage. 40:386-389.

Ralphs, M.R., M.M. Kothmann, and C.A. Taylor. 1990. Vegetation response to increased stocking rates in short-duration grazing. J. Range Manage. 43:104-108

Savory, A. 1988. Holistic resource management. Island Press, Covelo, Calif.

Sims, P.L., and D.D. Dwyer. 1965. Pattern of retrogression of native vegetation in north central Oklahoma. J. Range Manage. 18:20-25.

Tainton, N.M., P. de V. Booysen, and R.C. Nash. 1977. The grazing rotation: Effects of different combinations of presence and absence. Proc. Grassl. Soc. South Africa. 12:103-104.

Thurow, T.L., W.H. Blackburn, and C.A. Taylor, Jr. 1988. Some vegetation responses to selected livestock grazing strategies, Edwards Plateau, Texas. J. Range Manage. 41:108-114.

Towne, G., and C. Owensby. 1984. Long-term effects of annual burning at different dates in ungrazed Kansas tallgrass prairie. J. Range Manage. 37:393-397.

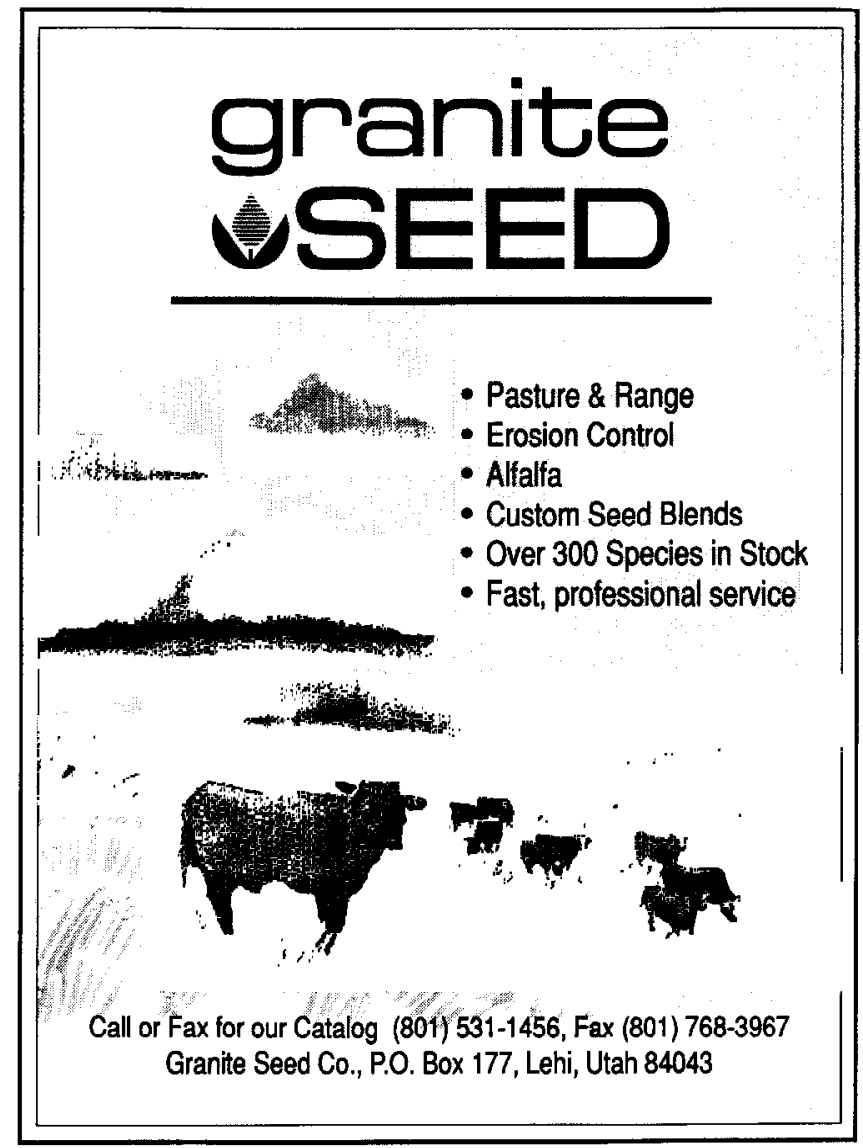

